\title{
Feeding specialization of bresiliid shrimps in the TAG site hydrothermal community
}

\author{
A. V. Gebruk ${ }^{1}$, N. V. Pimenov ${ }^{2}$, A. S. Savvichev ${ }^{2}$ \\ ${ }^{1}$ P. P. Shirshov Institute of Oceanology, Russian Academy of Sciences, Krasikova St. 23, Moscow 117218, Russia \\ ${ }^{2}$ Institute of Microbiology, Russian Academy of Sciences, Prosp. 60-Letyja Oktjabrja 7, Moscow 117811, Russia
}

\begin{abstract}
It is argued that the Atlantic bresiliid shrimps Rimicaris exoculata and Chorocaris chacei from a hydrothermal community on the Mid-Atlantic Ridge feed on exosymbiotic bacteria that form a dense covering on their mouthparts and the inner surface of the carapace. The associated bacterial community includes different morphological forms and types and is full of sulfide crystals from black smokers. Mouthparts of Atlantic hydrothermal bresiliids are hypertrophied and densely covered with setae to enlarge the attachment surface for associated bacteria. SEM revealed 2 dominant morphological types of filamentous bacteria with trichome width 0.2 to $0.5 \mu \mathrm{m}$ and 1 to $3 \mu \mathrm{m}$, with elemental sulfur inside the cells and with attaching disks; both forms resemble Thiothrix spp. The idea of a bacterial source of food for shrimp was strengthened by carbon stable-isotope analysis, which yielded $\delta^{13} \mathrm{C}=-10.5$ to $-12.5 \%$. Presumably, the shrimps keep close to hydrothermal fluid to farm their bacterial symbionts in the moderate current with a low concentration of hydrogen sulfide. The assayed level of ribulose 1,5-bisphosphate carboxylase activity in the bacterial community is low (2.2 $\mu$ mol $\mathrm{min}^{-1} \mathrm{~g}^{-1}$ protein), indicating dominance of heterotrophic forms among symbionts. The source of primary production in the vent community is discussed.
\end{abstract}

\section{INTRODUCTION}

Two caridean shrimps from the family Bresiliidae, Rimicaris exoculata and Chorocaris chacei, dominate the megafauna of the TAG site hydrothermal community found on the Mid-Atlantic Ridge $\left(26^{\circ} 08^{\prime} \mathrm{N}\right.$, $\left.44^{\circ} 49^{\prime} \mathrm{W}\right)$ at a depth of 3620 to $3700 \mathrm{~m}$. Many thousands of shrimp form dense swarms that hide the surface of the rocks around hydrothermal chimneys. Both species were described as Rimicaris in 1986 (Williams \& Rona 1986) from dredge material. Later, $R$. chacei was transferred to the genus Chorocaris (Martin \& Hessler 1990). A number of cruises to the TAG site from 1986 to 1991 with the submersibles 'Alvin', 'Mir-1' and 'Mir-2' (Rona 1986, Rona et al. 1986, Galkin \& Moskalev 1990) and some previous expeditions (Rona 1980) showed that shrimps in this community always keep close to black smoke or shimmering water.

Van Dover and colleagues (Van Dover 1988, Van Dover et al. 1988, 1989) found that Atlantic hydrothermal shrimps are blind but have a dorsal 2-lobed organ with a postulated thermosensory function. It was suggested (Van Dover et al. 1989) that these shrimps graze on free-living bacteria growing on the chelae and brush them off with modified mouthparts. The bacterial source of the food was demonstrated by carbon stableisotope analysis $\left(\delta^{13} \mathrm{C}=-11.6\right.$ to $-12.1 \%$ ) and by lipopolysaccharide assays of shrimp gut content. The presence of sulfide crystals in the gut was also reported. The role of symbiotic bacteria in shrimp feeding was thought not to be important (Van Dover et al. 1989).

However, a combination of suspension feeding with utilization of bacteria that cover the shrimp carapace was proposed by Jannasch et al. (1991).

In the present study we present further data on feeding biology of shrimps in the TAG site hydrothermal community, and try to determine the role of associated bacteria in shrimp feeding. Some of our results have been published in Russian in 2 short preliminary publications (Gebruk et al. 1992, Pimenov et al. 1992).

\section{MATERIALS AND METHODS}

Shrimps. Sixty-seven Rimicaris exoculata and 18 Chorocaris chacei individuals were collected during 
6 dives of the submersibles 'Mir-1' and 'Mir-2' on the active hydrothermal mound at the TAG site $\left(26^{\circ} 08^{\prime} \mathrm{N}\right.$, $44^{\circ} 49^{\prime} \mathrm{W}_{i} 3620$ to $3700 \mathrm{~m}$ ) in May to June 1991, on the 23rd cruise of RV 'Akademik Mstislav Keldysh'. The total length of the shrimps ranged from 23 to $58 \mathrm{~mm}$. Most of the material was preserved in formalin and stored in $70 \%$ EtOH. Some analyses were made on fresh material; the remainder was frozen. Direct observations from submersibles and $6 \mathrm{~h}$ of excellent video tape were used to examine shrimp behavior in situ.

Rock and substrate samples. Twelve samples of sulfide deposits from the vicinity of shrimp aggregations were collected with the manipulator, and using light microscopy were examined on board for the presence of bacterial covering on the rock surface. Several polychaete tubes with soft fringe-like bacterial covering were taken using the manipulator for morphological studies of associated bacteria. Some of the tubes were studied fresh in the laboratory and the remainder were preserved in $2 \%$ glutaraldehyde.

Microscopic analysis. Low magnification $(\times 150)$ was used to make drawings of different morphological types of symbiotic filamentous bacteria from the fresh material. Material prepared for SEM was dehydrated, critical-point dried and gold-coated. A JSM-T-130 microscope was used for SEM. A polarizing light microscope $(\times 150)$ was used for identification of sulfur inside fresh bacterial cells.

$\mathrm{CO}_{2}$ assimilation. Dark-bottle assimilation of $\mathrm{CO}_{2}$ was assayed in samples of the inconspicuous bacterial covering found on the surface of sulfides, and in $1.5 \mathrm{l}$ water samples taken $1 \mathrm{~m}$ above bottom in the vicinity of shrimp aggregations. The traditional radioisotope method with $\mathrm{NaH}^{14} \mathrm{CO}_{3}$ and an on-board Rackbeta scintillation counter was used. Two control samples were taken $1 \mathrm{~m}$ above bottom at a distance of $300 \mathrm{~m}$ from the hydrothermal field. All measurements were made on the ship, at an ambient temperature of ca $20^{\circ} \mathrm{C}$.

Stable-isotope analyses. Shrimp mouthparts, abdominal muscle, gills and whole organisms were analyzed for carbon isotopes with an MI-12-120JB isotope ratio mass-spectrometer using the technique of Dando et al. (1991). Results are given relative to the Pee Dee Belemnite (PDB) standard in the notation:

$$
\delta^{13} \mathrm{C}(\%)=\left(\frac{\left({ }^{13} \mathrm{C} /{ }^{12} \mathrm{C}\right)_{\text {sample }}}{\left({ }^{13} \mathrm{C} /{ }^{12} \mathrm{C}\right)_{\text {standard }}}-1\right) \times 1000
$$

Ribulose 1,5-bisphosphate carboxylase (RuBPCase) activity. Different shrimp tissues from the fresh material (gills, mouthparts, whole organisms) were macerated with quartz sand at 2 to $3^{\circ} \mathrm{C}$, and disintegrated by ultrasound (22 kHz) 3 times for $15 \mathrm{~s}$ using a UZDN-2T apparatus on board ship. The suspension was cen- trifuged for $20 \mathrm{~min}$ at $3^{\circ} \mathrm{C}$ and $8000 \mathrm{rpm}$. RuBPCase activity was assayed using the technique of Dando et al. (1985).

The number of autotrophic sulfur bacteria cells in water samples taken in the vicinity of shrimp swarms was estimated from incubation in the growth medium described in Kuenen \& Veldhamp (1972).

\section{RESULTS}

\section{Shrimp behavior in situ}

Shrimp behavior was observed in situ and recorded on videotape during 6 dives of 'Mir-1' and 'Mir-2'. The densest shrimp aggregations occurred close to the black smoker complex on top of the hydrothermal mound, whose dimensions were approximately $250 \times 180 \mathrm{~m}$ wide at the base and $70 \mathrm{~m}$ high. Large aggregations were also found in the shimmering water zone, 20 to $40 \mathrm{~m}$ from the black smokers. Occasional shrimp occur at the periphery of the hydrothermal community and even up to $300 \mathrm{~m}$ from the vent field. No direct measurements of water temperature were made around the shrimp. Temperature in the shirmmering water was measured at 20 to $40^{\circ} \mathrm{C}$. In aggregations most shrimp remain on the surface of the black smoker chimneys, grappling the substrate with their anterior appendages and legs. The water around shrimp aggregations is turbulent, because of mixing of the water column with the hot hydrothermal fluid. Shrimp seem to change their position on the substrate occasionally, in most cases being detached by water turbulence. When that happens, they swim actively but without specific orientation back towards the substrate. Most of the time, shrimp fight water turbulence to avoid being removed from the local area. In the shimmering water zone shrimp are less mobile, spending most of the time at one particular place, holding on to the substrate.

\section{Functional morphology of shrimps}

The 2 species are morphologically similar. We limit ourselves to details that may be important for feeding biology.

The carapace, especially of Rimicaris exoculata, wraps almost entirely around the body, forming chambers along either side. Anterior appendages (antennular and antennal flagella) are strong and heavy, with scattered inconspicuous sensory setae at joints between annuli. The antennular and antennal peduncles are hypertrophied, and their joints allow mainly vertical movement. The exopods of maxilliped 1 and maxilla 2 are atypical for bresiliids, being enormously expanded and densely covered with setae (Fig. 1). Dense fields of setae 

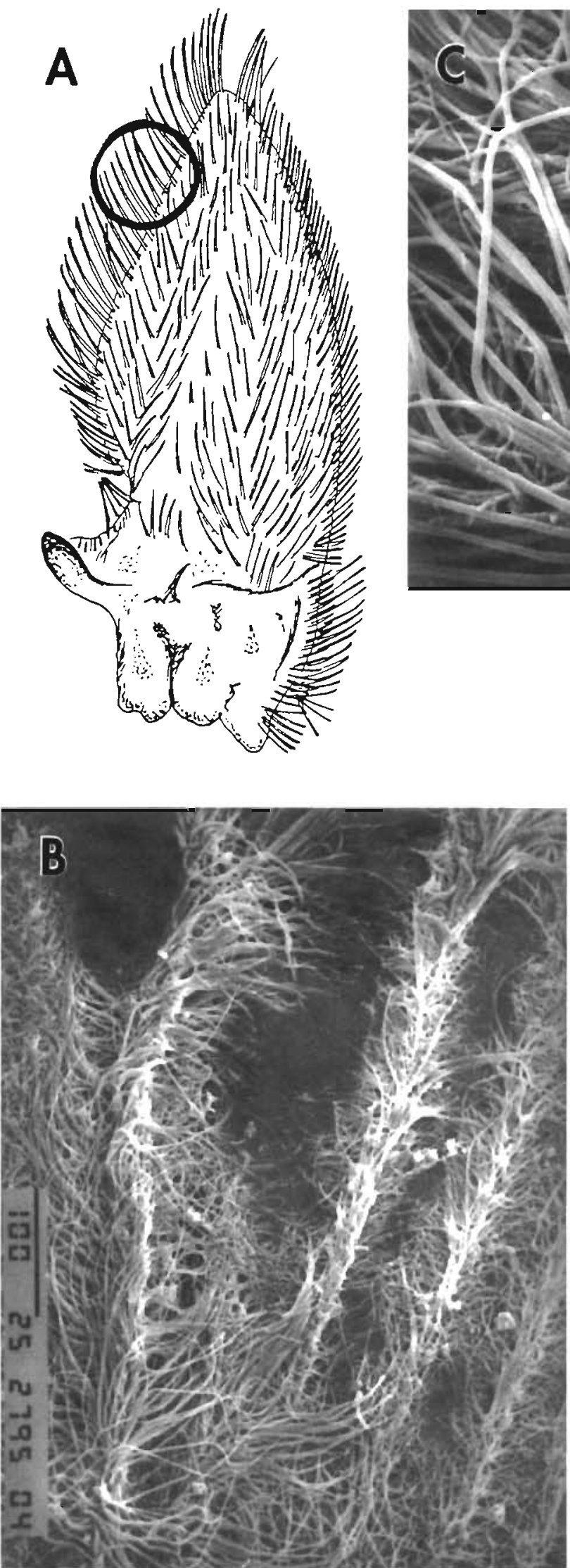
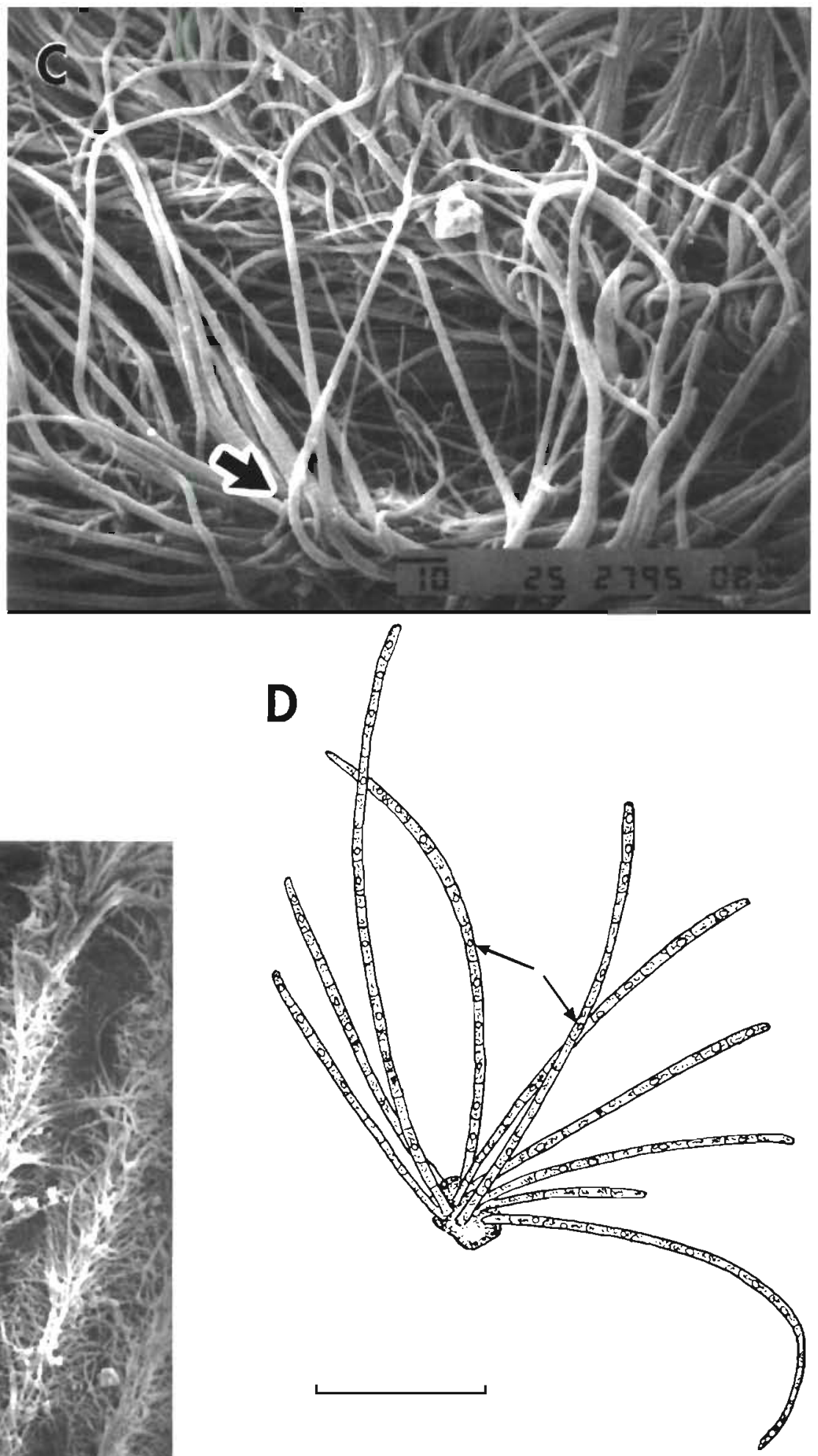

Fig. 1. Rimicaris exoculata. (A) Exopodite of maxilla 1 (the part magnified in (B) is circled); (B) filamentous bacterial covering on setae (scale bar $=100 \mu \mathrm{m}$ ); $(\mathrm{C})$ filamentous bacteria, forming bush-like colonies (arrow points to the attaching disk) (scale bar $=10 \mu \mathrm{m}$ ); (D) bush-like colony with the attaching disk (scale bar $=10 \mu \mathrm{m}$, arrows indicate sulfur globules) 
also cover most of the mouthparts. The last segment of the endopodite of maxilliped 2 is brush-like, especially in $R$. exoculata. Small chelae are present on the first pair of legs (pereiopods 1).

\section{Associated bacteria}

A complex community of associated microflora was found on shrimp mouthparts and on the inner surface of the carapace. Two forms of filamentous bacteria, both forming bush-like colonies with attaching disks, dominate in this community (Figs. $1 \& 2$ ). They contain elemental sulfur inside the cells. This condition is diagnostic for colorless sulfur bacteria. Both forms resemble Thiothrix spp. Trichome width is 0.2 to $0.5 \mu \mathrm{m}$ in one form and 1 to $3 \mu \mathrm{m}$ in the other. There are many gormogonia among the filaments (Fig. 2). The associated bacterial community also includes rodshaped forms 1 to $3 \mu \mathrm{m}$ long, considerable mucus and a lot of sulfide crystals. The carapace area of some shrimp looks dark, or even black, due to these crystals.

\section{Stable-isotope analysis}

For a whole Rimicaris exoculata and Chorocaris chacei individual the $\delta^{13} \mathrm{C}$ level is -10.5 to $-12.5 \%$ $(-10.5$ to $-12.1 \%$ and -11.6 to $-12.5 \%$ respectively); for mouthparts of both species, $\delta^{13} \mathrm{C}=-16 \%$ ( 2 individuals); for both abdominal muscle and gills $-13.1 \%$, and for abdominal muscle + mouthparts $-15.1 \%$ (all the latter for $R$. exoculata)

\section{$\mathrm{CO}_{2}$ assimilation}

Dark-bottle assimilation of $\mathrm{CO}_{2}$ in the water sample taken $1 \mathrm{~m}$ above bottom in the vicinity of shrimp was 250 to $1300 \mathrm{ng} \mathrm{Cl}{ }^{-1}(24 \mathrm{~h})^{-1}$ (6 samples), and $920 \mathrm{ng} \mathrm{C} \mathrm{kg}^{-1}$ $\left(24 \mathrm{~h}^{-1}\right.$ (1 sample) in the samples of bacterial filaments from the surface of hydrothermal sulfides. Two control

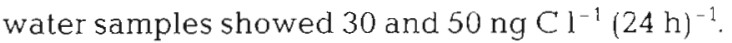

\section{Ribulose 1,5-bisphosphate carboxylase activity}

Activity of RuBPCase, an enzyme diagnostic for $\mathrm{CO}_{2}$ assimilation, was assayed in the fresh sample of asso- ciated bacteria. Enzyme activity was found to reach $2.2 \mu \mathrm{mol} \mathrm{min}-1 \mathrm{~g}^{-1}$ protein.

\section{Free-living bacteria in the water column}

The number of autotrophic sulfur bacteria cells was counted in the water samples taken close to hydrothermal fluid immediately above the shrimp. This number was approximately 100 cells $\mathrm{ml}^{-1}$. No other types of bacteria were found in the water samples.

\section{DISCUSSION}

\section{Evidence for bacterial diet of shrimp}

The possibility of a bacterial food source of Rimicaris exoculata in the TAG site hydrothermal community required confirmation, even after the study of Van Dover et al. (1988) had strongly suggested its presence. Our data from carbon stable-isotope analysis provided this confirmation. In addition no difference was found in the ${ }^{13} \mathrm{C}$ level between $R$. exoculata and Chorocaris chacei. The $\delta^{13} \mathrm{C}$ values of shrimps $(-10.5$ to $-12.5 \%$ ) are similar to those of some other hydrothermal animals: -9.6 to $-11.2 \%$ for Alvinella pompejana, -9.0 to $-13.3 \%$ for Riftia pachyptila (review in Fisher 1990). The value of $\delta^{13} \mathrm{C}=-16 \%$ assayed separately for shrimp mouthparts probably results from light-isotope lipids in the filamentous sulfur bacteria and other associated forms.

\section{Primary role of associated bacteria in shrimp feeding}

The high population density of shrimp in the TAG site hydrothermal community requires a large standing crop of bacterial cells on the surface of sulfide deposits, if shrimps feed by grazing. We found no evidence for a large standing crop of free-living bacteria, neither during observations and videotype analysis, nor on substrate samples. There were only rare bacterial filaments forming local inconspicuous networks on the surface of sulfides and a soft fringe-like filamentous bacterial covering on some polychaete tubes at the periphery of the vent community. In both cases the covering was formed by the same morphological type of bacteria that inhabit shrimp mouthparts. The absence of a distinct bacterial mat is an unusual

Fig. 2. Rimicaris exoculata. (A) Two types of associated bacterial filaments: (1) trichome width 0.2 to $0.3 \mu \mathrm{m}$, (2) trichome width 1 to $3 \mu \mathrm{m}$. (B) Two morphological types of bacterial filaments; arrow indicates gormogonium. 





feature of the TAG site, rarely found in vent communities elsewhere. The number of bacterial cells in the water column above the shrimp was also very low (100 cells $\left.\mathrm{ml}^{-1}\right), 3$ to 4 times less than in Pacific vent communities (Jannasch 1985). We conclude from these data that the standing crop of free-living bacteria at the TAG site is not enough to support the shrimp population, and infer that the shrimps' associated microflora has a primary role in shrimp feeding.

Two types of filamentous bacteria, both of which resemble Thiothrix spp., dominate in the associated bacterial community. The attaching disk of bush-like colonies and the occurrence of bacterial growth on the inner surface of carapaces indicate that the bacteria were not picked up from the substrate.

The total amount of exosymbiotic bacteria on each individual seems to be enough to supply the shrimp with food, though quantitative analysis of energy flow between host and symbiont remains to be conducted.

Details of external morphology indicate that shrimp are highly specialized for carrying bacterial symbionts and utilizing them. Cavities formed by the carapace along either side of the body, hypertrophied exopods of maxilla 2 and maxilliped 1 , and dense fields of setae on the mouthparts enlarge the attaching surface for symbionts. These morphological features are unique, and not typical of other bresiliid shrimps. We consider this specialized morphology as one of the main arguments for the symbiosis between the shrimp and bacteria.

We suggest that the following mechanism is employed for utilization of bacteria. The chelipeds pick the bacteria from the inner surface of the carapace or from the mouthparts; the bacteria are transferred into the basket formed by maxilliped 2 and the rest of the mouthparts, from which they are brushed into the mouth by the endopodite of maxilliped 2. Brushing by the scoop-shaped chela of pereiopod 1 is also possible (Van Dover et al. 1988).

Most of the filamentous, colorless sulfur bacteria live in a moderate current in which hydrogen sulfide concentration is low. We infer that shrimp bacterial symbionts find these conditions at the TAG site. Low hydrogen sulfide concentration in hydrothermal fluid is typical for this area: 4 to $6 \mathrm{mmol} \mathrm{kg}{ }^{-1}$ (Rudnicki 1990) which is 2 to 3 times less than in the Guaymas Basin, for example. Water current is generated by turbulence around the black smokers and by the shimmering water, and that seems to be the reason why shrimps aggregate just in the vicinity of hydrothermal fluid. To monitor hot venting water, shrimp use their dorsal thermosensory organ (Van Dover 1988, Van Dover et al. 1989). Sulfide crystals from the hydrothermal fluid settle on dense fields of setae covered with associated bacteria, and get into the gut together with bacterial food. When water turbulence is low, shrimp are able to keep on the surface of the substrate by grappling with their specialized anterior appendages and dactylous legs. It is likely that shrimp can use hypertrophied antennae and antennular peduncles to ventilate their ventral surface and cavities formed by the carapace, where the symbiotic bacteria live; the peduncular articulation allows primarily vertical movement. Thus bacteria find favourable conditions on the bodies of shrimp that probably suit them better than the open substrate. This form of symbiosis seems to be very unusual, with a high degree of specialization. The idea of favourable conditions for bacterial growth, created by shrimp, was discussed also by Segonzac (1992) (though he supported a grazing type of shrimp feeding) and by Jannasch et al. (1991) (who discussed a suspension-feeding type).

Direct measurements using autoradiography are required to support the present idea of symbiosis. But this is extremely hard to carry out because of the complicated high-pressure equipment required and because of the many problems involved in the culturing of filamentous, colorless sulfur bacteria.

The most recent microbiological data revealed high enzymatic $\mathrm{CO}_{2}$ reduction (30 to $40 \mathrm{nmol} \mathrm{CO}_{2}$ fixed $\mathrm{mg}^{-1}$ protein $\mathrm{h}^{-1}$ ) in bacterial filaments that cover the inner surface of shrimp carapaces (Jannasch et al. 1991). This makes evident the key role of chemosynthetic activity of the exosymbiotic bacteria in primary production in the TAG site hydrothermal community.

There is evidence for symbiotrophic feeding based on exosymbiotic bacteria for some other hydrothermal animals: alvinellid polychaetes (Gail \& Hunt 1991) and the limpet gastropod Lepetodrilus fucensis (de Burgh \& Singla 1984). In both cases, the host animals utilize bacteria cells directly or use products of bacterial metabolism. According to recent data (Kim \& Ohta 1991) from the Iheya Ridge hydrothermal community at the Mid-Okinawa Trough, another hydrothermal bresiliid shrimp, Alvinocaris sp., was recorded with associated filamentous bacteria. Exosymbiotic bacteria thus seem to play an important role in the feeding strategies of hydrothermal animals.

Acknowledgements. We thank the crew of RV 'Akademik Mstislav Keldysh' led by Captain A. M. Korobov, and the diving group of the submersibles 'Mir-1' and 'Mir-2', with Dr A. M. Sagalevich as the head, for helping us fulfil the programme of the 23rd cruise and obtain the unique material. Special thanks to Dr Peter A. Rona (NOAA), who took part in the cruise, for his information about the TAG site hydrothermal field, and to Dr Robert R. Hessler for constructive criticism in reading the manuscript, and for correction of English usage. This research was supported from the budget of the USSR Academy of Sciences and the P. P. Shirshov Institute of Oceanology. 


\section{LITERATURE CITED}

Dando, P. R., Austen, M. C., Burke, R. A. Jr, Kendall, M. A., Kennicutt, M. C. II, Judd, A. G., Moore, D. C., O'Hara, S. C. M., Schmaljohann, R., Southward, A. J. (1991). Ecology of a North Sea pockmark with an active methane seep. Mar. Ecol. Prog. Ser. 70: 49-63

Dando, P. R., Southward, A. J., Southward, E. C., Terwilliger, N. B., Terwilliger, R. C. (1985). Sulphur-oxidizing bacteria and haemoglobin in gills of the bivalve mollusc Myrtea spinifera. Mar. Ecol. Prog. Ser. 23: 85-98

de Burgh, M. E., Singla, C. L. (1984). Bacterial colonization and endocytosis on the gill of a new limpet species from a hydrothermal vent. Mar. Biol. 84(1): 1-6

Fisher, C. P. (1990). Chemoautotrophic and methanotrophic symbioses in marine invertebrates. Rev. aquat. Sci. $2(3,4)$ : $399-436$

Gail, F., Hunt, S. (1991). The biology of annelid worms from high temperature hydrothermal vent regions. Rev. aquat. Sci. 4(2,3): 107-137

Gal'chenko, V. F., Ivanov, M. V., Lein, A. J. (1989). Microbiological and biogeochemical processes in the oceans' water columns, as indicators of underwater hydrothermal activity. Geochimija 8: 1075 (in Russian)

Galkin, S. V., Moskalev, L. 1. (1990). Hydrothermal fauna of the Mid-Atlantic Ridge. Okeanologia, Mosk. 30(5): 842-847 (in Russian)

Gebruk, A. V., Pimenov, N. V., Savvichev, A. S. (1992). Bacterial 'farm' on the shrimp mouthparts. Priroda (Moscow) 6: 37-39 (in Russian)

Jannasch, H. W. (1985). The chemosynthetic support of life and the microbial diversity at deep-sea hydrothermal vents. Proc. R. Soc. B 225: 277-297

Jannasch, H. W., Wirsen, C. O., Molyneaux, S. J. (1991) Chemosynthetic microbial activities at the $23^{\circ}$ and $26^{\circ} \mathrm{N}$ Mid-Atlantic Ridge vent sites. Ridge Events, November: 19

Kim, D. S., Ohta, S. (1991). Submersible observations and comparison of the biological communities of the two hydrothermal vents on the Iheya Ridge of the Mid-Okinawa Trough. JAMSTECTR Deep Sea Res. 1: 222-233

This article was submitted to the editor
Kuenen, J. G., Veldhamp, R. (1972). Thiomicrospira pelophila nov. gen. nov. sp. a new obligately chemolithotrophic colorless sulfur bacterium. Antonie van Leeuwenhoek 38: $241-256$

Martin, J., Hessler, R. (1990). Chorocaris vandoverae, a new genus and species of hydrothermal vent shrimp (Crustacea, Decapoda, Bresiliidae) from the Western Pacific. Contr. Sci. 417: 1-11

Pimenov, N. V., Savvichev, A. S., Gebruk, A. V., Moskalev, L. I., Lein, A. J., Ivanov, M. V. (1992). Trophical specialization of bresiliid shrimps in the TAG site hydrothermal community. Dokl. Akad. Nauk 323(3): 567-571 (in Russian)

Rona, P. A. (1980). TAG hydrothermal field: Mid-Atlantic Ridge crest at latitude $26^{\circ} \mathrm{N}$. J. geol. Soc. Lond. 137 $385-402$

Rona, P. A. (1986). Direct observations of Atlantic black smokers. EOS 67(46): 1327

Rona, P. A., Klinkhammer, G., Nelsen, T A., Tretry, J. H., Elderfield, H. (1986). Black smokers, massive sulfides and vent biota at the Mid-Atlantic Ridge. Nature 321: 33

Rudnicki, M. D. (1990). Hydrothermal plumes at the MidAtlantic Ridge. Ph.D. dissertation, Univ. of Cambridge, Cambridge

Segonzac, M. (1992). The hydrothermal vent communities of Snake Pit area (Mid-Atlantic Ridge; $23^{\circ}$ N, $3480 \mathrm{~m}$ ): megafaunal composition and microdistribution. C.r. Acad. Sci., Paris 314(3): 593-600

Van Dover, C. L. (1988). Do 'eyeless' shrimp see the light of glowing deep-sea vents? Oceanus 31(4): 47-52

Van Dover, C. L., Fry, B., Grassle, J F., Humphris, S., Rona, P. A. (1988). Feeding biology of the shrimp Rimicaris exoculata at hydrothermal vents on the Mid-Atlantic Ridge. Mar. Biol. 98: 209-216

Van Dover, C. L., Szuts, E. Z., Chamberlain, S. C., Cann, J. R. (1989). A novel eye in 'eyeless' shrimp from hydrothermal vents of the Mid-Atlantic Ridge. Nature 337(6206): 458-460

Williams, A. B., Rona, P. A. (1986). Two new caridean shrimps (Bresiliidae) from a hydrothermal field on the Mid-Atlantic Ridge. J. crust. Biol. 6(3): 446-462

Manuscript first received: January 7, 1993

Revised version accepted: March 29, 1993 